\title{
Public Spending and National Income Before and After Economic Reform in China: An Application of Asymmetric Threshold Cointegration
}

\author{
Ching-Yang Liang ${ }^{1} \&$ Chih-Wen $\mathrm{Mao}^{2}$ \\ ${ }^{1}$ Department of Finance and Taxation, Takming University of Science and Technology, Taipei, Taiwan \\ ${ }^{2}$ Department of Public Finance and Tax Administration, National Taipei College of Business, Taipei, Taiwan \\ Correspondence: Ching-Yang Liang, Department of Finance and Taxation, Takming University of Science and \\ Technology. No.56, Sec. 1, Huanshan Rd., Neihu District, Taipei City 11451, Taiwan, Republic of China. Tel: \\ 886-2-2658-5801 ext. 5274. E-mail: cyliang@takming.edu.tw
}

$\begin{array}{ll}\text { Received: August 15, } 2013 & \text { Accepted: September 26, } 2013 \quad \text { Online Published: October 26, } 2013 \\ \text { doi:10.5539/ijef.v5n11p1 } & \text { URL: http://dx.doi.org/10.5539/ijef.v5n11p1 }\end{array}$

\begin{abstract}
This paper re-examines Wagner's law of an expanding government sector with progress of the economy for China. This study divides the sample into two periods: "pre-reform" (1960-1978) and "post-reform" (19792009). The empirical results indicate that a long-run relationship between national income and public spending does exist in the "pre-reform" and "post-reform" period. The results show that unidirectional Granger causality from national income to public spending is found in the "post-reform" period, thus providing support for Wagner's law. Alternatively, no causal relationship between public spending and national income is found in the "pre-reform" period, thus lending no support to the validity of Wagner's law.
\end{abstract}

Keywords: Wagner's Law, economic reform, threshold cointegration

\section{Introduction}

Economists have concentrated on the relationship between public spending and national income for a long time. One classic approach for explaining the relationship is the "Law of the Increasing Extension of State Activity" by Wagner (1890), which has come to be known as Wagner's Law. This view suggests that public spending tends to increase at a faster pace than the rate of growth of the economy. The main objective of this article is to re-examine the validity of Wagner's law to China over the period between 1960 and 2009. More importantly, this paper focuses on the role of Chinese economic reform by the end of 1978, which divides our sample into two periods: the "pre-reform" period (1960-1978) and the "post-reform" period (1979-2009). We separate the sample in 1978 for the reason that China launched economic reforms and adopted an opening-up policy by the end of 1978. Since 1979, China has transformed itself from a centrally planned economy to an emerging market economy, from a rural to an urban society, and from agriculture to manufacturing and services. Reform in China in the past quarter century represents the most extraordinary economic and social transformation the world has witnessed (Hussain \& Tern, 2008). Therefore, it is worth noticing whether Wagner's law holds for China before or after Chinese economic reform.

China's "reform and open-up policy" has had an enormous effect on China's economic landscape in recent quarters. Between 1979 and 2009, China's GDP increased by more than 17 times, and the average growth rate was $9.93 \%$; China's per capita GDP increased by approximately 12 times, and the average growth rate was $8.76 \%$. During this period, government expenditure increased by more than 13 times, and the average growth rate was $9.68 \%$. As announced by the World Bank (2010), China surpassed Japan as the world's second-largest economy in the second quarter of 2010. By excluding redistributive functions through social security and noncontributory transfers, which take up more than half of government spending in advanced OECD countries, the size of China's government is already comparable to the advanced OECD countries regarding share of GDP (Dollar \& Ofman, 2008). Therefore, there is a need to understand the nexus between public spending and national income in China before and after Chinese economic reform.

From the viewpoint of public finance, a transition from a command economy to a market economy is essentially a complex redistribution of claims to income and of responsibilities for expenditures by the state, enterprises, 
and households. Therefore, the relationship between public spending and national income may be seen as reverse patterns before and after Chinese economic reform. Hussain and Stern (2008) argued that before 1978, there was little difference to public finance whether an expenditure item was financed by enterprises or directly by government in China. However, after 1978, particularly after enterprise budgets separated from government budgets, the financing division between enterprises and government has become of major importance, because expenditure liability request the entity to bear the responsibility for financing it. Hussain and Stern (2008) also observed that government investment in industrial and other economic activities fell sharply in China after 1978. The share of capital construction financed by the government budget shrank, from more than $40 \%$ in 1978 to $12 \%$ in 2004 , and the share of expenditures devoted to culture, education, and health rose steadily. This change corresponded with the transformation in responsibility for providing social goods from enterprises to government. For this reason, we expect support for Wagner's law in the "post-reform" period in China while the opposite will be shown in the "pre-reform" period.

Few studies have been conducted on Wagner's law for China. Cotsomitis, Harnhirun, and Kwan (1996) suggested that Wagner's law holds for China over the period 1952-1992. Huang (2006) indicated that Wagner's law is not valid over the period 1979-2002. The present study significantly differs from previous studies. This paper concentrates on an economy that transforms from a Soviet-type system to a market system. The current study refers to the "pre-reform" period as a Soviet-type system and the "post-reform" period as an emerging market system to observe whether a different type of economic system results in different public spending and national income condition.

This study adopts the asymmetric threshold cointegration model to test for cointegration between public spending and national income. We do not employ the cointegration analysis method proposed by Engle-Granger or Johansen based on the fact that these conventional methods represent two extremes. Their conclusions are frequently "yes" or "no" cointegration without presenting an intermediate situation or condition (Shen \& Chen, 2003). However, the exhibition or expression of cointegration can vary according to various economic conditions. For example, cointegration exists when the economy is good, but does not exist when the economy is bad. These methods cannot manage or process this type of situation. In addition, within conventional methods, it is merely hypothesized that the error correction term adjustment method is symmetric, indicating that, regardless of a positive or negative equilibrium error, the error correction adjustment coefficient remains identical. Therefore, regardless of a vital or depressed economy, the adjustment speed is the same. If there is an asymmetric equilibrium or unbalanced relationship between public spending and national income, the employment of conventional methods may not show this effect because of the neglect of asymmetry. Therefore, we used the asymmetric threshold cointegration model developed by Enders and Siklos (2001). The error correction term adjustment method of this model is asymmetrical. When the equilibrium error between public spending and national income is positive, the error correction term adjustment coefficient is not the same as when equilibrium error is negative.

The remainder of this study is organized as follows. Section 2 provides an overview of selected literature. Section 3 describes a theoretical formulation of Wagner's law. Section 4 presents the econometric methodology. Section 5 shows the empirical results. Section 6 concludes the paper.

\section{Literature Review}

Research has spurred intense debate in the literature over the last three decades regarding the validity of Wagner's law. Voluminous empirical works have been dedicated to cross-country estimates to test Wagner's law. These studies assess the elasticity of government expenditure with respect to GDP. If the elasticity significantly exceeds unity (one), it can be regarded as evidence for Wagner's hypothesis. Abizadeh and Gray (1985) explored 55 countries during the period from 1963 to 1979, and argued that Wagner's law holds for the developing countries group; however, it does not hold for the poor and the developed countries group. Ram (1986) indicated extremely limited support for Wagner's law from the post-War 63-country scenario. Ram (1987) indicated that while Wagner's law seems to be supported in about $60 \%$ of 115 countries in time-series data covering the period 1950-1980, such support is lacking in most cross-section estimates.

However, other researchers have investigated Wagner's law using time-series estimates. The analysis begins with an examination of Wagner's law using the unit roots test, the cointegration test, and the Granger causality test. First, each series is examined for its stationary properties using the unit roots test. Second, if "public spending" and "national income" are found to be I(1), the long-run relationship would be estimated using the cointegration test. The final analysis determines the short-run dynamics of "public spending" and "national income" relations by the Granger causality test. Wagner's law states that if a long-run relationship between public spending and 
national income is established, unidirectional causality from national income to public spending is required. Bohl (1996) showed that the establishment for Wagner's law applied only to Canada and the United Kingdom out of the G7 countries during the post-World War II period. Anwar, Davies, and Sampath (1997) examined 88 countries over the period 1960-1992 and found that the findings of only 13 countries supported the validity of Wagner's law. Ansari, Gordon, and Akuamoah (1997) found that Wagner's law is not valid for three African countries. Thornton (1999) found evidence of Wagner's law in five out of six countries. Kolluri, Panik, and Wahab (2000) presented the validity of Wagner's law from the G7 countries. Al-Faris (2002) found evidence of Wagner's law in the Gulf Cooperation Council countries. Chang (2002) tested six countries over the period 1951-1996 and found the results lend support to Wagner's law, except for Thailand. Iyare and Lorde (2004) detected evidence contradicting Wagner's law regarding nine Caribbean countries, with the exception of Grenada, Guyana, and Jamaica. Chang, Liu, and Caudill (2004) discovered support for Wagner's law in five countries out of a sample of ten countries. Wahab (2004), and Kolluri and Wahab (2007) suggested that Wagner's law is valid when GDP growth decelerates to below the trend for the OECD countries group, while it is invalid when GDP growth accelerates above the trend. Lamartina and Zaghini (2011) provided evidence for the validity of Wagner's law in 23 OECD countries.

On the other hand, several country-specific studies have investigated Wagner's law using time-series estimates. These empirical studies have yielded conflicting results from developed countries to developing countries. Ahsan, Kwan, and Sahni (1996) found evidence in Canada, while Biswal, Dhawan, and Lee (1999) found no evidence in Canada. Narayan, Prasad, and Singh (2008) found evidence in Fiji. Chletsos and Kollias (1997) and Dritsakis and Adamopoulos (2004) found no evidence in Greece. Burney (2002) found no evidence in Kuwait. Oxley (1994) and Chow, Cotsomitis, and Kwan (2002) found evidence in the United Kingdom. Yousefi and Abizadeh (1992) and Islam (2001) found evidence in the United States.

\section{Model Specification and Data}

Wagner's law states the relationship between "economic progress" and "growth of state activity," that is, public spending increases as a country's income rises. However, it is not clear how "national income" and "public spending" are defined. The literature has used three proxies to measure "public spending": government expenditure, government expenditure per capita, and share of government expenditure to GDP. Two proxies have been used to measure "national income": GDP and GDP per capita. Given the implicit nature of Wagner's law, this paper employs five formulations prevailing in the literature to review the validity of the law.

Model 1: $\ln G_{t}=a+b \ln Y_{t}+\varepsilon_{t}$.

Model 2: $\ln G_{t}=a+b \ln \left(Y_{t} / N_{t}\right)+\varepsilon_{t}$.

Model 3: $\ln \left(G_{t} / N_{t}\right)=a+b \ln \left(Y_{t} / N_{t}\right)+\varepsilon_{t}$.

Model 4: $\ln \left(G_{t} / Y_{t}\right)=a+b \ln \left(Y_{t} / N_{t}\right)+\varepsilon_{t}$.

Model 5: $\ln \left(G_{t} / Y_{t}\right)=a+b \ln Y_{t}+\varepsilon_{t}$.

where $G$ is real government expenditure, $Y$ is real GDP, $N$ is population, $Y / N$ is real GDP per capita, $G / Y$ is share of real government expenditure to real GDP, $G / N$ is real government expenditure per capita, $t$ is time subscript, and $\varepsilon$ is random error term. Model 1 represents Peacock and Wiseman's (1961) version, Model 2 is referred to as Goffman's (1968) version, Model 3 describes Gupta's (1967) version, Model 4 reports Musgrave's (1969) version, and Model 5 displays Mann's (1980) version.

Based on available data, the sample covers the period 1960-2009 in this paper. Government expenditure $(G)$, GDP $(Y)$, and population $(N)$ data are obtained from World Development Indicators (WDI) published by the World Bank. Figure 1 presents the plot of public spending and national income. In Figure 1, the development of the economy is accompanied by increased public expenditure, with a slow upward trend both before and after 1978 . 


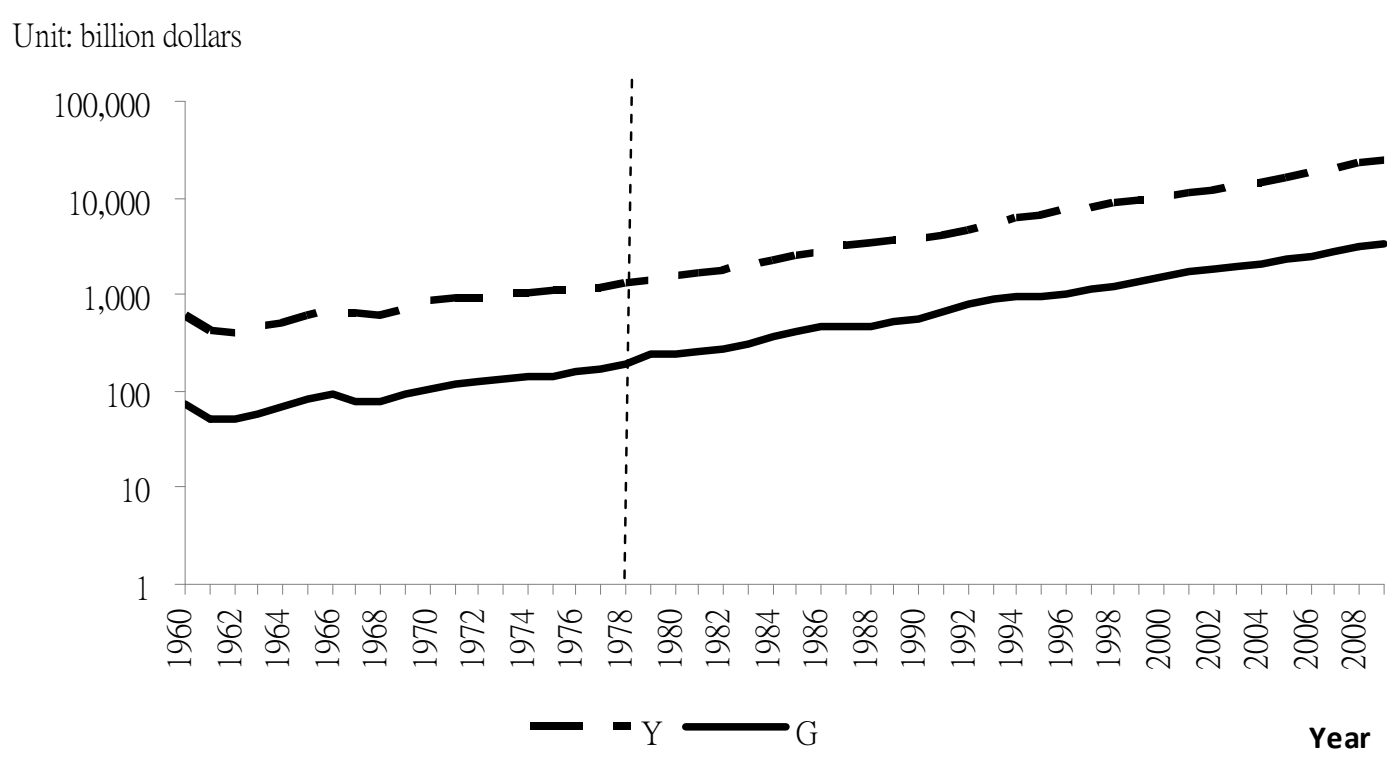

Figure 1. Public spending and national income

As suggested by Hall, Anderson, and Granger (1992), Fuhrer (1996), Lanne (1999), and Bohl and Siklos (2004), findings from the entire sample may not be appropriate when the whole period includes various monetary policy regimes. Similarly, when the sample period covers different economic regimes, such as the Soviet-type system and the market system in this paper, it may be proper to split the sample. As outlined in Section 1, 1978 is a natural candidate for separating the sample. Therefore, we divide our sample into two periods: "pre-reform" (1960-1978) and "post-reform" (1979-2009).

\section{Methodology}

To test the validity of Wagner's law, conventional studies make an effort to assess the elasticity of government expenditure with respect to the GDP. If the elasticity significantly exceeds unity (one), it can be regarded as evidence in support of Wagner's hypothesis. By contrast, this paper adopts the asymmetric threshold cointegration model to test for cointegration between public spending and national income, and uses the threshold error-correction model to test for the causality between public spending and national income. The empirical analysis proceeds in three steps. First, the data series is subjected to tests for unit roots. Second, we test for possible cointegration relationships between public spending and national income. The final step determines the direction of causation among the variables. Wagner's law states that if a long-run relationship between public spending and national income is established, unidirectional causality from national income to public spending is required. Furthermore, we used the threshold error-correction model to test for causality between public spending and national income.

\subsection{Unit Root Test}

The analysis begins with an examination of Wagner's law using unit roots test, cointegration test, and Granger Causality test. To determine whether each of the series is stationary, unit root tests are conducted on "public spending" and "national income." This study uses both the augmented Dickey-Fuller test (ADF, 1979, 1981) and the Phillips-Perron test (PP, 1988) to test unit roots.

\subsection{Cointegration Test}

Because "public spending" and "national income" are integrated of order one, I(1), it is appropriate to examine the long-run relationship between "public spending" and "national income." Following Engle and Granger (1987), the cointegration equation is estimated as follows:

$$
g_{t}=\alpha+\beta y_{t}+\varepsilon_{t}
$$

where $g_{t}$ is "public spending" proxied by three variables $(G, G / Y$, and $G / N)$ and $y_{t}$ is "national income" proxied by two variables $\left(Y\right.$ and $Y / N$ ). The residuals $\varepsilon_{t}$ represent the disequilibrium between "national income" and "public spending." 
In the second step, cointegration is tested based on the ordinary least squares (OLS) estimate of $\rho$ in the following equation:

$$
\Delta \hat{\mu}_{t}=\theta \hat{\varepsilon}_{t-1}+\sum_{i=1}^{k} \gamma_{i} \Delta \hat{\varepsilon}_{t-i}+\mu_{t}
$$

where $\mu_{t}$ is a white-noise disturbance and $k$ is lag length. The null hypothesis of no cointegration is rejected if $-2<\theta<0$. It is worth to note that the standard vector correction model implicitly assumes that the adjustment process for "public spending" and "national income" due to disequilibrium is symmetric. If, however, the adjustment is asymmetric, then the assumption of symmetric adjustment implies model misspecification.

Enders and Granger (1998) indicated that the discrimination is crucial because unit root test and cointegration test all have lower power in the presence of an asymmetric adjustment process. For this purpose, this paper investigates the existence of cointegration between "public spending" and "national income" using asymmetric modeling. The investigation employs the TAR (threshold autoregressive) model and M-TAR (momentum threshold autoregressive) model developed by Enders and Granger (1998) and Enders and Siklos (2001).

The TAR model is estimated from Equation 3 and 4, while the M-TAR model is estimated from Equation 3 and 5:

$$
\Delta \hat{\varepsilon}_{t}=I_{t} \theta_{1} \hat{\varepsilon}_{t-1}+\left(1-I_{t}\right) \theta_{2} \hat{\varepsilon}_{t-1}+\sum_{i=1}^{k} \delta_{i} \Delta \hat{\varepsilon}_{t-i}+v_{t}
$$

where $v_{t}$ is a white-noise disturbance and $k$ is lag length. The Heaviside indicator functions, $I_{t}$, are denoted as follows:

$$
\begin{aligned}
I_{t} & = \begin{cases}1 & \text { if } \hat{\varepsilon}_{t-1} \geq \phi \\
0 & \text { if } \hat{\varepsilon}_{t-1}<\phi\end{cases} \\
I_{t} & = \begin{cases}1 & \text { if } \Delta \hat{\varepsilon}_{t-1} \geq \phi \\
0 & \text { if } \Delta \hat{\varepsilon}_{t-1}<\phi\end{cases}
\end{aligned}
$$

where $\phi$ is the value of the threshold and is endogenously determined using Chan's (1993) method. The necessary conditions for $\left\{\hat{\varepsilon}_{t}\right\}$ to be stationary are that $\theta_{1}$ and $\theta_{2}$ must be negative.

The TAR model allows the adjustment to depend on the previous period's disequilibrium, $\hat{\varepsilon}_{t-1}$. If $\hat{\varepsilon}_{t-1}$ rises above the long-run equilibrium, the adjustment is captured by $\theta_{1} \hat{\varepsilon}_{t-1}$; alternatively, if $\hat{\varepsilon}_{t-1}$ falls below the long-run equilibrium, the adjustment is captured by $\theta_{2} \hat{\varepsilon}_{t-1}$. In employing the TAR model, it is probable to observe whether the positive discrepancies from long-run equilibrium have different effects on the behavior of "national income" and "public spending" than do the negative discrepancies.

However, the M-TAR model allows the adjustment to depend on the previous period's change in disequilibrium, $\Delta \hat{\varepsilon}_{t-1}$. In employing the M-TAR model, it is probable to observe whether the positive change of discrepancies from long-run equilibrium has a different effect on the behavior of "national income" and "public spending" than does the negative change of discrepancies.

In the TAR model and M-TAR model, the null hypothesis of no cointegration can be tested by the restriction $\theta_{1}=\theta_{2}=0$, while the null hypothesis of symmetry can be tested by the restriction $\theta_{1}=\theta_{2}$. Rejecting both the null hypotheses of $\theta_{1}=\theta_{2}=0$ and $\theta_{1}=\theta_{2}$ implies the existence of threshold cointegration with asymmetric adjustment.

\subsection{Granger Causality Test}

Final analysis is related to the short-run dynamics of "public spending" and "national income" relations. Given the evidence in favor of asymmetric cointegration between "public spending" and "national income," this study applies Granger causality tests using the asymmetric error-correction model (Enders \& Granger, 1998; Enders \& Siklos, 2001) expressed as follows: 


$$
\begin{aligned}
& \Delta g_{t}=a_{0}+\omega_{11} I_{t} \hat{\varepsilon}_{t-1}+\omega_{12}\left(1-I_{t}\right) \hat{\varepsilon}_{t-1}+\sum_{i=1}^{k} a_{1 i} \Delta g_{t-i}+\sum_{i=1}^{k} a_{2 i} \Delta y_{t-i}+\xi_{1 t} \\
& \Delta y_{t}=b_{0}+\omega_{21} I_{t} \hat{\varepsilon}_{t-1}+\omega_{22}\left(1-I_{t}\right) \hat{\varepsilon}_{t-1}+\sum_{i=1}^{k} b_{1 i} \Delta g_{t-i}+\sum_{i=1}^{k} b_{2 i} \Delta y_{t-i}+\xi_{2 t}
\end{aligned}
$$

where $\xi_{1 t}$ and $\xi_{2 t}$ are white-noise disturbances, and $k$ is lag length.

The null hypothesis of $a_{2 i}=0, i=1 \ldots k$ is applied to test the short-run causal relation running from "national income" to "public spending" in Equation (6), while the null hypothesis of $b_{1 i}=0, i=1 \ldots k$ is applied to test the short-run causal relation running from "public spending" to "national income" in Equation (7).

\section{Empirical Results}

\subsection{Unit Root Test Estimations}

Prior to examining the cointegrating relationship between "public spending" and "national income", each series is first examined for its stationary property. Table 1 presents the results of the unit root tests for $G$ (government expenditure), $Y$ (GDP), $G / Y$ (share of government expenditure to GDP), $G / N$ (government expenditure per capita), and $Y / N$ (GDP per capita). The selection of lag length is determined by the minimum Akaike information criterion (AIC).

\begin{tabular}{|c|c|c|c|c|}
\hline \multirow{2}{*}{0} & \multicolumn{2}{|c|}{ 1960-1978 } & \multicolumn{2}{|c|}{ 1979-2009 } \\
\hline & $\mathrm{ADF}$ & PP & $\mathrm{ADF}$ & PP \\
\hline$G$ & -0.209 & 0.065 & -1.416 & -0.118 \\
\hline$k$ & 3 & 1 & 6 & 2 \\
\hline$\Delta^{\circ} G$ & $-4.677 * * *$ & $-5.023 * * *$ & $-3.981 * * *$ & $-4.710^{* * *}$ \\
\hline$k$ & 4 & 1 & 5 & 2 \\
\hline$G / N$ & -0.191 & -0.337 & 0.579 & 0.171 \\
\hline$k$ & 3 & 1 & 7 & 2 \\
\hline$\triangle G / N$ & $-4.568 * * *$ & $-4.818 * * *$ & $-4.384 * * *$ & $-4.684 * * *$ \\
\hline$k$ & 4 & 1 & 5 & 2 \\
\hline$G / Y$ & -1.328 & -2.110 & -0.209 & -2.065 \\
\hline$k$ & 3 & 1 & 7 & 2 \\
\hline${ }^{\circ} G / Y$ & $-4.304 * * *$ & $-6.978 * * *$ & $-3.087 * *$ & $-5.079 * * *$ \\
\hline$k$ & 1 & 1 & 7 & 2 \\
\hline$Y$ & -1.134 & 0.012 & -0.306 & 0.373 \\
\hline$k$ & 1 & 1 & 3 & 2 \\
\hline$\Delta Y$ & $-3.436^{* *}$ & $-4.993 * * *$ & $-3.769 * * *$ & $-3.147 * *$ \\
\hline$k$ & 4 & 1 & 5 & 2 \\
\hline$Y / N$ & -1.266 & -0.443 & 0.327 & 0.914 \\
\hline$k$ & 1 & 1 & 3 & 2 \\
\hline$\triangle Y / N$ & $-3.989 * * *$ & $-4.789 * * *$ & $-3.346^{* *}$ & $-3.081^{* *}$ \\
\hline$k$ & 4 & 1 & 5 & 2 \\
\hline
\end{tabular}

Table 1. Unit root test results

Notes: $\Delta$ denotes the first difference operator. $\mathrm{k}$ is lag length determined by minimum AIC. $*, * *, * *$ denote statistical significance at the $10 \%, 5 \%$, and $1 \%$ levels, respectively.

Based on statistics of the unit root test under the ADF and PP tests, the null hypothesis of a unit root is not rejected at the $10 \%$ significance level for the variables in their level form in the two periods. However, it is possible to reject the null hypothesis of a unit root at the $5 \%$ significance level for the variables in their first-difference form in the two periods. Thus, the first-differences of "public spending" and "national income" are deemed stationary and their levels are non-stationary. Results reveal that the $G, G / Y, G / N, Y$, and $Y / N$ series are integrated of order one, I(1), in the "pre-reform" period (1960-1978) and "post-reform" period (1979-2009) 


\subsection{Cointegration Test Estimations}

Because "public spending" and "national income" are found to be I(1), the long-run relationship was estimated using the symmetric Engle-Granger method outlined in Equation 2. Table 2 reports the results of the Engle-Granger method. The null hypothesis of $\theta=0$ is rejected, indicating a long-run relationship exists between "public spending" and "national income" in the "pre-reform" period and "post-reform" period. As previously noted, the Engle-Granger model assumes that the adjustment back to the long-run equilibrium relationship is symmetric. However, if the adjustment is asymmetric, then the Engle-Granger model may imply model misspecification.

Table 2. Engle-granger cointegration test results

\begin{tabular}{lcccc}
\hline \multirow{2}{*}{ Model } & $1960-1978$ & \multicolumn{2}{c}{$1979-2009$} \\
\cline { 2 - 5 } & $\theta$ & $k$ & $\theta$ & $k$ \\
\hline \multirow{2}{*}{ Model 1: $G$ and $Y$} & $-0.855^{* * *}$ & 0 & $-0.841^{* * *}$ & \multirow{2}{*}{$(-5.401)$} \\
Model 2: $G$ and $Y / N$ & $-3.444)$ & 0 & $-0.613^{* * *}$ & 2 \\
& $-0.901^{* * *}$ & 0 & $(-3.999)$ & 2 \\
Model 3: $G / N$ and $Y / N$ & $-0.873^{* * *}$ & & $-0.851^{* * *}$ & 2 \\
Model 4: $G / Y$ and $Y / N$ & $(-3.577)$ & 0 & $(-5.476)$ & 2 \\
& $-0.873^{* * *}$ & 0 & $-0.851^{* * *}$ & 2 \\
Model 5: $G / Y$ and $Y$ & $(-3.577)$ & 0 & $(-5.476)$ & 2 \\
& $-0.855^{* * *}$ & 0 & $-0.841^{* * *}$ & \multirow{2}{*}{2} \\
\hline
\end{tabular}

Notes: $\mathrm{t}$-statistic are in parentheses. $\theta$ denotes statistics for the null hypothesis of no cointegration. $\mathrm{k}$ is lag length determined by minimum AIC. *,**,** denote statistical significance at the $10 \%, 5 \%$, and $1 \%$ levels, respectively.

The residuals $\varepsilon_{t}$ from Equation 1 are used to estimate the TAR model and M-TAR model that allow asymmetric adjustment. Table 3 reports the results of this two models. The first column shows the results from the TAR model over the period 1960-1978. The estimates of $\theta_{1}$ and $\theta_{2}$ indicate that the TAR model does not satisfy the stationarity conditions. At the $5 \%$ significance level, Model 3 and Model 4 reject the null hypothesis of no cointegration. However, the null hypothesis of symmetry is not rejected in these five models. In this case, asymmetry in the cointegrating relationship between "public spending" and "national income" is not established in the TAR model. Therefore, estimating with symmetric cointegration in the "pre-reform" period is proper.

Table 3. TAR and M-TAR cointegration test results

\begin{tabular}{lcccc}
\hline \multirow{2}{*}{0} & \multicolumn{2}{c}{$1960-1978$} & \multicolumn{2}{c}{$1979-2009$} \\
\cline { 2 - 5 } & TAR & M-TAR & TAR & M-TAR \\
\hline & & Model $1: G$ and $Y$ & & \\
$\theta_{1}$ & 0.028 & -0.059 & 0.057 & -0.005 \\
$\theta_{2}$ & -0.696 & $-3.960^{* * *}$ & $-0.616^{* * *}$ & $-0.818^{* * *}$ \\
$\theta_{1}=\theta_{2}$ & $(-0.780)$ & $(-4.283)$ & $(-3.948)$ & $(-3.808)$ \\
$\theta_{1}=\theta_{2}$ & 2.955 & -0.365 & -0.269 & $-0.368^{* *}$ \\
$k$ & $(1.146)$ & $(-0.496)$ & $(-1.315)$ & $(-2.352)$ \\
& 5.555 & $10.187^{* * *}$ & $7.798^{* *}$ & $8.543^{* *}$ \\
$\phi$ & 3.684 & 7.700 & 2.605 & $3.552^{*}$ \\
$\theta_{1}$ & {$[0.195]$} & {$[0.109]$} & {$[0.122]$} & {$[0.074]$} \\
$\theta_{2}$ & 7 & 7 & 9 & 9 \\
\hline
\end{tabular}




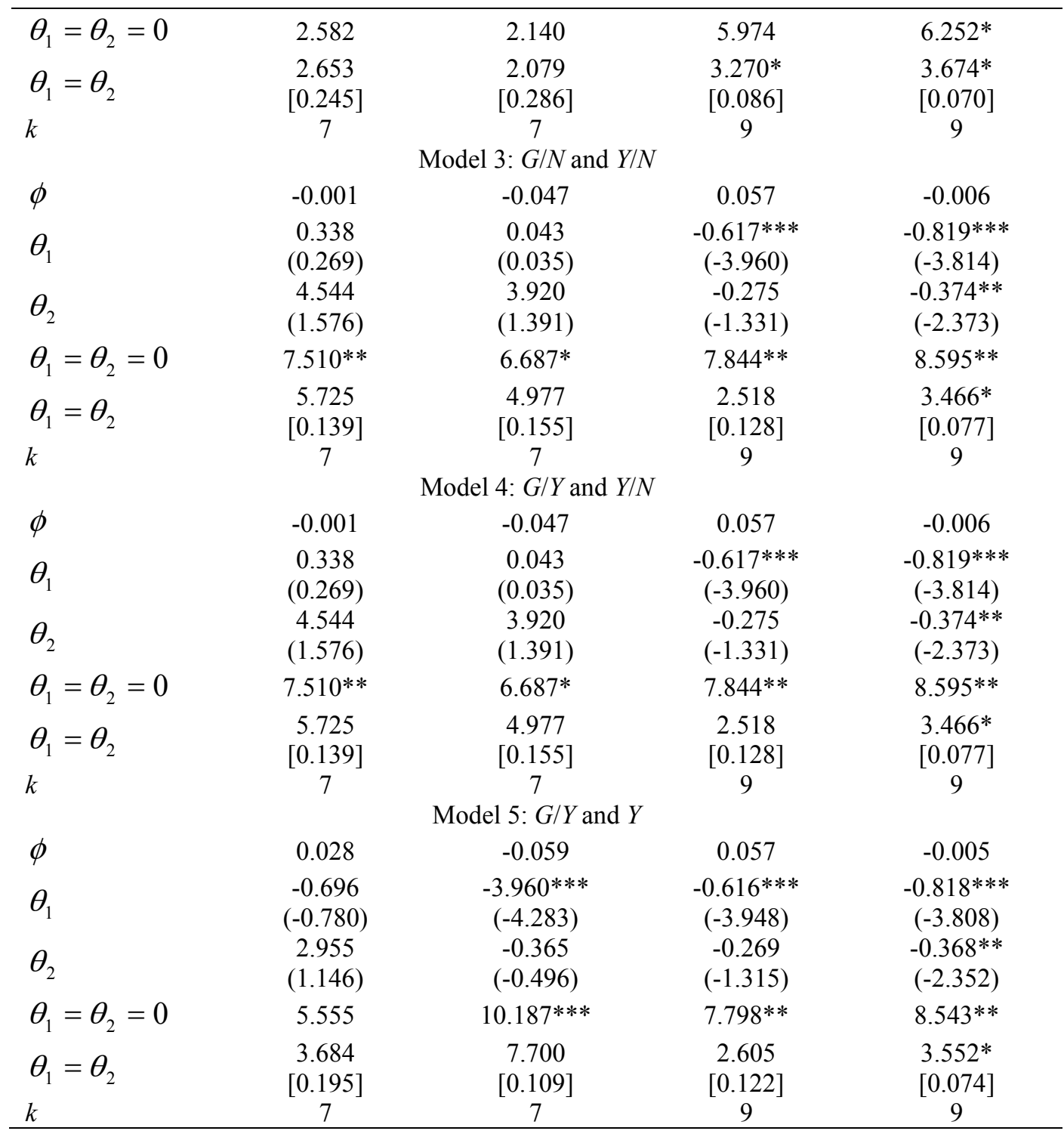

Notes: t-statistic are in parentheses. p-values are in brackets. $\theta_{1}=\theta_{2}=0$ denotes statistics for the null hypothesis of no cointegration. $\theta_{1}=\theta_{2}$ denotes statistics for the null hypothesis of symmetry. $\mathrm{k}$ is lag length determined by minimum AIC. The critical values for the TAR model given by Enders and Siklos (2001) are 6.20, 7.31, and 10.00 at the 10\%, 5\%, and 1\% significance levels, respectively. The critical values for the M-TAR model given by Enders and Siklos (2001) are 5.99, 7.14, and 9.93 at the 10\%, 5\%, and 1\% significance levels, respectively. *,**, *** denote statistical significance at the $10 \%, 5 \%$, and $1 \%$ levels, respectively.

The second column reports the results from the M-TAR model over the period 1960-1978. The estimates of $\theta_{1}$ and $\theta_{2}$ indicate that the M-TAR model does not satisfy the stationarity conditions. The null hypothesis of no cointegration is rejected at the $10 \%$ significance level except in Model 2. However, the null hypothesis of symmetry is not rejected in these five models. Thus, there is no asymmetric cointegration between "public spending" and "national income" in the M-TAR model. Therefore, it is appropriate to estimate with symmetric cointegration in the "pre-reform" period.

The third column shows the results from the TAR model over the period 1979-2009. The estimates of $\theta_{1}$ and $\theta_{2}$ indicate that the TAR model satisfies the stationarity conditions. At the $5 \%$ significance level, the null hypothesis of no cointegration is rejected, except in Model 2. However, the null hypothesis of symmetry is not rejected, except in Model 2. This finding suggests that the asymmetric cointegrating relationship between "public spending" and "national income" is not established in the TAR model in the "post-reform" period.

The fourth column reports the results from the M-TAR model over the period 1979-2009. The estimates of $\theta_{1}$ and $\theta_{2}$ indicate that the M-TAR model satisfies the stationarity conditions. The null hypothesis of no 
cointegration is rejected at the $10 \%$ significance level in these five models, indicating that cointegration exists in "public spending" and "national income." Given the cointegration of "public spending" and "national income," it is possible to test the null hypothesis of symmetric adjustment. Based on the F-statistic, it is possible to reject symmetric adjustment in these five models at the $10 \%$ significance level. These results support the existence of a long-run relationship between "public spending" and "national income" and the presence of asymmetries in the adjustment process toward long-run equilibrium. Therefore, it is proper to estimate with asymmetric cointegration in the "post-reform" period.

Enders and Siklos (2001) suggested that the M-TAR model can be especially valuable when policy makers are viewed as attempting to moderate any large shocks in a series. In addition, Enders and Siklos (2001) demonstrated that the power of the test for TAR model is poor compared to the Engle-Granger model. However, for a plausible range of the adjustment parameters, the power of the M-TAR model can be many times the Engle-Granger model. Based on the mentioned reasons, this paper selects the M-TAR model to test the validity of Wagner's law.

\subsection{Granger Causality Test Estimations}

Establishing the cointegration between "public spending" and "national income" makes it is possible to estimate their short-run dynamic using Granger causality tests with an error-correction model. Table 4 reports the results of the Granger causality test. Given the negative finding of asymmetric cointegration in the "pre-reform" period, the analysis employs a symmetric error correction model. The first column reports the results in the "pre-reform" period The F-statistics indicates that "public spending" is not Granger-caused by "national income" and that "national income" is not Granger-caused by "public spending" in these five models. In other words, the null hypothesis of $a_{2 i}=0$ and $b_{1 i}=0$ cannot be rejected. No causal relationship between "national income" to "public spending" is found in China in the "pre- reform" period. This finding provides no evidence for the validity of Wagner's law in China over the period 1960-1978.

Table 4. Granger causality test results

\begin{tabular}{lcc}
\hline & $1960-1978$ & $1979-2009$ \\
\hline Model 1: $G$ and $Y$ & & \\
$a_{2 i}=0$ & $0.880[0.665]$ & $3.488^{* *}[0.013]$ \\
$k$ & 5 & 10 \\
$b_{1 i}=0$ & $2.088[0.480]$ & $0.832[0.606]$ \\
$k$ & 5 & 10 \\
Model 2: G and Y/N & & \\
$a_{2 i}=0$ & $1.005[0.636]$ & $3.452^{* *}[0.014]$ \\
$k$ & 5 & 10 \\
$b_{1 i}=0$ & $1.408[0.562]$ & $1.244[0.273]$ \\
$k$ & 5 & 1 \\
Model 3: G/N and Y/N & $1.138[0.608]$ & $2.689 * *[0.036]$ \\
$a_{2 i}=0$ & 5 & 7 \\
$k$ & $1.644[0.529]$ & $1.892[0.516]$ \\
$b_{1 i}=0$ & 5 & 15 \\
$k$ & & \\
Model 4: G/Y and Y/N & $24.197[0.153]$ & $3.160 * *[0.020]$ \\
$a_{2 i}=0$ & 5 & 10 \\
$k$ & $1.644[0.529]$ & $1.096[0.420]$ \\
$b_{1 i}=0$ & 5 & 10 \\
$k$ & & \\
Model 5: G/Y and Y & $25.877[0.148]$ & $2.194 *[0.075]$ \\
$a_{2 i}=0$ & 5 & 9 \\
$k$ & $2.088[0.480]$ & $0.832[0.606]$ \\
$b_{1 i}=0$ & 5 & 10 \\
$k$ & &
\end{tabular}

Notes: p-values are in brackets. $a_{2 i}=0$ is statistics for null hypothesis of no Granger causality from $y$ to $g$. $b_{1 i}=0$ is statistics for null hypothesis of no Granger causality from $g$ to $y$. $\mathrm{k}$ is lag length determined by minimum AIC. *, **, *** denote statistical significance at the $10 \%, 5 \%$, and $1 \%$ levels, respectively. 
By contrast, the positive finding of asymmetric cointegration with the M-TAR adjustment in the "post-reform" period implies it is incorrect to examine the short-run dynamics with a symmetric error correction model. Hence, the analysis employs asymmetric error correction models outlined in Equations 6 and 7. The second column reports the results in the "post-reform" period. The F-statistics indicates that "public spending" is Granger-caused by "national income" and that "national income" is not Granger-caused by "public spending." That is to say, the null hypothesis of $a_{2 i}=0$ can be rejected, but the hypothesis of $b_{1 i}=0$ cannot be rejected. Unidirectional Granger causality running from "national income" to "public spending" seems to hold for China in the "post-reform" period. This evidence indicates that Wagner's law is found in China over the period 19792009.

\section{Conclusion}

Wagner's law has been the topic of considerable interest in public finance literature. To date, testing of the validity of Wagner's law has been confined to developed and developing countries. Almost no study has considered an economy transformed from a Soviet-type system to a market system. China is one of the most remarkable representatives in the world since its economic reform by the end of 1978. This paper re-examines the validity of Wagner's law for China over the period 1960-2009 using an asymmetric threshold cointegration model. Due to the particularity of economic reform by the end of 1978 , this paper split the sample into two periods: "pre-reform" (1960-1978) and "post-reform" (1979-2009).

In the "post-reform" period, the results corresponding to the cointegration test show that the null hypothesis of no cointegration with asymmetric adjustment can be rejected. Support exists for the existence of a long-run relationship between public spending and national income with an adjustment speed that is more rapid for positive discrepancy than for negative. That is, discrepancy from long-term equilibrium resulting from increases in public spending or decreases in national income are eliminated relatively quickly, whereas other changes display a large amount of persistence. The results corresponding to the Granger causality test show that unidirectional Granger causality is found running from national income to public spending. Therefore, the results indicate that Wagner's law is valid in China over the period 1979-2009.

In the "pre-reform" period, the results corresponding to the cointegration test show that the null hypothesis of no cointegration with symmetric adjustment can be rejected. A long-run relationship exists between public spending and national income with symmetric adjustment. The results corresponding to the Granger causality test find no causal relationship between public spending and national income and reveal that Wagner's law is not supported in China over the period 1960-1978.

\section{Reference}

Abizadeh, S., \& Gray, J. (1985). Wagner's law: A pooled time-series, cross-section comparison. National Tax Journal, 88, 209-218.

Ahsan, S. M., Kwan, A. C. C., \& Sahni, B. S. (1996). Cointegration and wagner's hypothesis: Time series evidence for Canada. Applied Economics, 28, 1055-1058. http://dx.doi.org/10.1080/000368496328182

Ansari, M. I., Gordon, D. V., \& Akuamoah, C. (1997). Keynes versus Wagner: Public expenditure and national income for three African countries. Applied Economics, 29, 543-550. http://dx.doi.org/10.1080/000368497327038

Al-Faris, A. F. (2002). Public expenditure and economic growth in the gulf cooperation council countries. Applied Economics, 34, 1187-1193. http://dx.doi.org/10.1080/00036840110090206

Anwar, M. S., Davies, S., \& Sampath, R. K. (1996). Causality between government expenditures and economic growth: An examination using co-integration techniques. Public Finance, 51, 166-184.

Biswal, B., Dhawan, U., \& Lee, H. Y. (1999). Testing Wagner versus Keynes using disaggregated public expenditure data for Canada. Applied Economics, 31, 1283-1291. http://dx.doi.org/10.1080/000368499323490

Bohl, M. T. (1996). Some international evidence on Wagner's law. Public Finance, 51, 185-200.

Bohl, M. T., \& Siklos, P. L. (2004). The Bundesbank's inflation policy and asymmetric behavior of the German term structure. Review of International Economics, 12, 495-508. http://dx.doi.org/10.1111/j.1467-9396.2004.00463.x

Burney, N. A. (2002). Wagner's Hypothesis: Evidence from Kuwait using cointegration tests. Applied Economics, 34, 49-57. http://dx.doi.org/10.1080/00036840010027540 
Chan, K. (1993). Consistency and limiting distribution of the least squares estimator of a threshold autoregressive model. The Annals of Statistics, 21, 520-533. http://dx.doi.org/10.1214/aos/1176349040

Chang, T. (2002). An econometric test of Wagner's Law for six countries based on cointegration and error-correction modelling techniques. Applied Economics, 34, 1157-1169. http://dx.doi.org/10.1080/00036840110074132

Chang, T., Liu, W., \& Caudill, S. B. (2004). A re-examination of Wagner's Law for ten countries based on cointegration and error-correction modelling techniques. Applied Financial Economics, 14, 577-589. http://dx.doi.org/10.1080/0960310042000233872

Chletsos, M., \& Kollias, C. (1997). Testing Wagner's Law using disaggregated public expenditure data in the case of Greece: 1958-93. Applied Economics, 29, 371-377. http://dx.doi.org/10.1080/000368497327155

Chow, Y. F., Cotsomitis, J. A., \& Kwan, A. C. C. (2002). Multivariate cointegration and causality tests of Wagner's Hypothesis: Evidence from the UK. Applied Economics, 34, 1671-1677. http://dx.doi.org/10.1080/00036840110115659

Cotsomitis, J. A., Harnhirun, S., \& Kwan, A. C. (1996). Co-integration analysis and the long run validity of Wagner's hypothesis: Evidence from the People's Republic of China. Journal of Economic Development, $21,1-10$.

Dickey, D. A., \& Fuller, W. A. (1979). Distribution of the estimators for autoregressive time series with a unit root. Journal of American Statistical Association, 74, 427-31. http://dx.doi.org/10.2307/2286348

Dickey, D. A., \& Fuller, W. A. (1981). Likelihood ratio statistics for autoregressive time series with a unit root. Econometrica, 49(4), 1057-72. http://dx.doi.org/10.2307/1912517

Dollar, D., \& Hofman, B. (2008). Intergovernmental fiscal reforms, expenditure assignment, and governance. In J. Lou, \& S. Wang (Eds.), Public finance in China: Reform and growth for a harmonious society (pp. 3951). Washington, DC: World Bank.

Dritsakis, N., \& Adamopoulos, A. (2004). A causal relationship between government spending and economic development: An empirical examination of the Greek economy. Applied Economics, 36, 457-464. http://dx.doi.org/10.1080/00036840410001682151

Enders, W., \& Granger, C. W. J. (1998). Unit root tests and asymmetric adjustment with an example using the term structure of interest rates. Journal of Business and Economic Statistics, 16, 304-311. http://dx.doi.org/10.2307/1392506

Enders, W., \& Siklos, P. L. (2001). Cointegration and threshold adjustment. Journal of Business and Economic Statistics, 19, 166-176. http://dx.doi.org/10.1198/073500101316970395

Engle, R. F., \& Granger, C. W. J. (1987). Co-integration and error-correction: Representation, estimation and testing. Econometrica, 55, 251-76. http://dx.doi.org/10.2307/1913236

Fuhrer, J. C. (1996). Monetary policy shifts and long-term interest rates. Quarterly Journal of Economics, 111, 1183-1209. http://dx.doi.org/10.2307/2946712

Goffman, I. J. (1968). On the empirical testing of Wagner's Law: A technical note. Public Finance, 23, 359-364.

Gupta, S. P. (1967). Public expenditure and economic growth: A time-series analysis. Public Finance, 22, 423461.

Hall, A. D., Anderson, H. M., \& Granger, C. W. J. (1992). A cointegration analysis of treasury bill yields. Review of Economics and Statistics, 74, 116-126. http://dx.doi.org/10.2307/2109549

Huang, C. (2006). Government expenditures in China and Taiwan: Do they follow Wagner's Law? Journal of Economic Development, 31, 139-148.

Hussain, A., \& Stern, N. (2008). Public finance, the role of the state, and economic transformation, 1978-2020. In J. Lou, \& S. Wang (Eds.), Public Finance in China: Reform and growth for a harmonious society (pp. 13-38). Washington, DC: World Bank.

Islam, A. M. (2001). Wagner's Law revisited: Cointegration and exogeneity tests for the USA. Applied Economics Letters, 8, 509-515. http://dx.doi.org/10.1080/13504850010018743

Iyare, S. O., \& Lorde, T. (2004). Co-integration, causality and Wagner's Law: Tests for selected caribbean countries. Applied Economics Letters, 11, 815-825. http://dx.doi.org/10.1080/1350485042000254881 
Kolluri, B. R., Panik, M. J., \& Wahab, M. S. (2000). Government expenditure and economic growth: Evidence from G7 countries. Applied Economics, 32, 1059-1068. http://dx.doi.org/10.1080/000368400322110

Kolluri, B., \& Wahab, M. (2007). Asymmetries in the conditional relation of government expenditure and economic growth. Applied Economics, 39, 2303-2322. http://dx.doi.org/10.1080/00036840600707126

Lamartina, S., \& Zaghini, A. (2011). Increasing public expenditure: Wagner's Law in OECD countries. German Economic Review, 12, 149-164. http://dx.doi.org/10.1111/j.1468-0475.2010.00517.x

Lanne, M. (1999). Near unit roots and the predictive power of yield spreads for changes in long-term interest rates. Review of Economics and Statistics, 81, 393-398. http://dx.doi.org/10.1162/003465399558328

Musgrave, R. A. (1969). Fiscal systems. New Haven: Yale University Press.

Narayan, P. K., Prasad, A., \& Singh, B. (2008). A test of the Wagner's Hypothesis for the Fiji Islands. Applied Economics, 40, 2793-2801. http://dx.doi.org/10.1080/00036840600972472

Oxley, L. (1994). Cointegration, causality and Wagner's Law: A test for Britain 1870-1913. Scottish Journal of Political Economy, 41, 286-298. http://dx.doi.org/10.1111/j.1467-9485.1994.tb01127.x

Peacock, A. T., \& Wiseman, J. (1961). The growth of public expenditure in the United Kingdom. Oxford: Oxford University Press.

Phillips, P. C. B., \& Perron, P. (1988). Testing for a unit root in time series regression. Biometrika, 75, 335-346. http://dx.doi.org/10.2307/2336182

Ram, R. (1986). Causality between income and government expenditure: A broad international perspective. Public Finance, 41, 393-414.

Ram, R. (1987). Wagner's hypothesis in time-series and cross-section perspectives: Evidence from "real" data for 115 countries. Review of Economics and Statistics, 69, 194-204. http://dx.doi.org/10.2307/1927226

Shen, C. H., \& Chen, C. F. (2003). Does B-Share's opening influence the efficiency of Chinese stock market? An application of asymmetric threshold cointegration. Journal of Financial Studies, 11, 89-119.

Thornton, J. (1999). Cointegration, causality and wagner's law in 19th century Europe. Applied Economics Letters, 6, 413-416. http://dx.doi.org/10.1080/135048599352916

Wahab, M. (2004). Economic growth and government expenditure: Evidence from a new test specification. Applied Economics, 36, 2125-2135. http://dx.doi.org/10.1080/0003684042000306923

Wagner, A. (1890). Finanzwissenchaft. Winter, C. F., Leipzig.

Yousefi, M., \& Abizadeh, S. (1992). Growth of state government expenditures: Empirical evidence from the United States. Public Finance, 47, 322-339.

\section{Copyrights}

Copyright for this article is retained by the author(s), with first publication rights granted to the journal.

This is an open-access article distributed under the terms and conditions of the Creative Commons Attribution license (http://creativecommons.org/licenses/by/3.0/). 